\title{
Effect of Mineral, Organic, Biofertilizers and Humic Acid on Vegetative Growth and Fruit Yield Quality of Caraway Plants (Carum carvi L.) El-Banna, H. Y. ${ }^{1}$ and K. F. Fouda ${ }^{2}$ \\ ${ }^{1}$ Veget. and Flori. Dept., Fac. Agric., Mansoura Univ. \\ ${ }^{2}$ Soil Sci. Dept., Fac. of Agric., Mansoura Univ., Egypt.
}

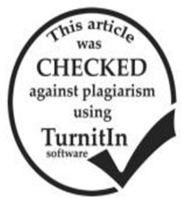

\begin{abstract}
Effects of different fertilizers types, i.e., mineral fertilizers (100\% as a control) or $30 \%$ combined with organic fertilizers (farmyard manure at 20 or $30 \mathrm{~m}^{3} / \mathrm{fed}$ ), bio-fertilizer and foliar application of humic acid on vegetative growth, yield and some nutrient contents of Caraway plant (Carum carvi L.) were studied at the Experimental station of Faculty of Agriculture, El-Mansoura University during the two growing seasons of 2016 and 2017. The results indicated that the highest mean values of the vegetative growth and fruit yield parameters of caraway plant were significantly increased when plants received $30 \%$ of the recommended mineral fertilizer combined with farmyard manure at $30 \mathrm{~m}^{3} /$ fed in the presence of bio-fertilizer and sprayed with humic acid as compared with control (NPK at 300,200 and $50 \mathrm{~kg} /$ fed, respectively). In addition; N, P and K percentage in herb and seeds recorded the highest values with the same previous treatment. While, the highest values of $\mathrm{NO}_{3}-\mathrm{N}$ concentration in herb and seeds was obtained with full recommended dose of mineral fertilization (control treatment).
\end{abstract}

\section{INTRODUCTION}

Caraway (Carum carvi L.) is one of the important medicinal and aromatic plants belong to the Apiaceae family. The dried fruit contain about $4-8 \%$ essential oil, which mainly consists of carvone $(52 \%)$ and limonene $(45 \%)$ as the principal components (Olle and Bender, 2010). Caraway seeds also contain nitrogen compounds (25-35\%), lipids (13-21\%), fiber (13-19\%), fatty oil (up to $22 \%$ ), water $(9-13 \%)$, protein compounds (up to $25 \%$ ) as well as flavonoids, sugars, organic acids, mineral salts, coumarin derivatives and other compounds (Kluszczyñska, 2002). Caraway fruit is used in food, meat and distillery industries due to its delightful flavor and strong taste (Kocourkova et al., 1999). In pharmaceutical applications it has important antibacterial and fungicidal properties (Sedlakova et al., 1998). It has also pain sedative, antiseptic, antispasmodic and antioxidant properties (Sembratowicz and Czech, 2005 and Dyduch et al., 2006).

It is well known that chemical fertilization is the widest method used for the production of most medicinal and aromatic plants but in many cases it has negative environmental effects including pollution of underground water, decreasing soil fecundity and destroying microorganisms (Ghosh and Bhat, 1998). Recently, the production of chemical free plants has a great interest of many producers and researchers especially after rejected many exports of important medicinal and aromatic crops because of the chemical residuals. In order to obviate these troubles and provide high quality and safety products, using organic and biological fertilizers or foliar application must be tested as alternatives to replace chemicals totally or partly.

Organic manure such as chicken manure contributes to plant growth through its effect on physical, chemical and biological properties of the soil. In addition, organic fertilizers provide soil with essential nutrients such as, N, P, S and some micro nutrients after its mineralization under soil conditions (El-Nagar, 1996). Bio-fertilizers include plant growth promoting bacteria having the capacity to fix the atmospheric nitrogen, dissolve the phosphorus and potassium of the soil and control the pathogen via producing plant growth regulators (Sturz and Christie, 2003). Bio-stimulators are one of the means for obtaining the increase in plant performance, among such substances is humic acids.
Application of humic acids has several benefits and agriculturists all over the world are accepting humic acids as an integral part of their fertilizer program and change physical properties of soil, (Fortun et al., 1989). Enhancement of plant growth using humic acid had been due to increasing nutrients uptake such as $\mathrm{N}, \mathrm{P}, \mathrm{K}, \mathrm{Mg}$, $\mathrm{Fe}, \mathrm{Zn}$ and $\mathrm{Cu}$, (Adani et al., 1998).

Therefore, the objective of the present study was to investigate the effect of using organic fertilizer, biofertilizers and humic acids as alternatives to mineral fertilizers on the growth, yield of Caraway plant which will help also to decrease the application of expensive chemical fertilizers leading to considerable reduction in production costs and pollution rates.

\section{MATERIALS AND METHODS}

The present study was conducted during the two successive winter seasons of 2016 and 2017 at the Experimental Station of the Medicinal and Aromatic Plants, Fac. Agric., Mansoura Univ.

Seeds of Caraway (Carum carvi L.) were obtained from Medicinal and Aromatic Plants Section of Agricultural Research Center, El- Dokky, Cairo, and sown on 5th November in both winter seasons. The experiment area was divided into plots of $5 \mathrm{~m} 2(2.0 \mathrm{~m}$ length and $2.5 \mathrm{~m}$ width) including four rows with $45 \mathrm{~cm}$ in width. Each row contained five hills at $30 \mathrm{~cm}$ plant spacing in one side. Thinning was performed after two weeks of planting to maintain two plants per hill and 60 plants per plot. After three weeks of seed sowing and complete germination thinning took place leaving two plants per hill. The soil is clay loam in texture. Some physical and chemical properties of the studied soil are shown in Table (1).

Three weeks before sowing the experimental farm was prepared, in each growing season as usually recommended. Control treatment was supplied with the full recommended dose of mineral fertilizers NPK as $200 \mathrm{Kg}$ / fed calcium superphosphate $(7 \% \mathrm{P})$ which was added during preparation of the soil, $300 \mathrm{Kg} / \mathrm{fed}$ ammonium sulfate $(20.5 \% \mathrm{~N})$ and $50 \mathrm{Kg} / \mathrm{fed}$ potassium sulphate $(40 \% \mathrm{~K})$ were added in two equal doses the first one was added one month after sowing and the second was applied at flowering stage. 
Table 1. Some physical and chemical analysis of experimental soil before the application of any fertilizers (mineral and organic).

\begin{tabular}{|c|c|c|c|}
\hline Soil characteristics & Values & \multicolumn{2}{|c|}{$\begin{array}{c}\text { Soluble cations and } \\
\text { anions (meq/100 g soil) }\end{array}$} \\
\hline $\begin{array}{l}\text { Physical properties \% } \\
\text { Coarse Sand } \\
\text { Fine Sand } \\
\text { Silt } \\
\text { Clay } \\
\text { Texture class }\end{array}$ & $\begin{array}{c}3.02 \\
31.65 \\
35.45 \\
29.88 \\
\text { clayloam }\end{array}$ & $\begin{array}{c}\mathrm{Ca}^{++} \\
\mathrm{Mg}^{++} \\
\mathrm{Na}^{+} \\
\mathrm{K}^{+} \\
\mathrm{CO}_{3}^{-} \\
\mathrm{HCO}_{3}^{-} \\
\mathrm{Cl}^{-} \\
\mathrm{SO}_{4}^{--}\end{array}$ & $\begin{array}{c}1.22 \\
0.79 \\
3.85 \\
0.08 \\
- \\
1.09 \\
3.29 \\
1.56\end{array}$ \\
\hline $\begin{array}{l}\text { Chemical properties } \\
\mathrm{CaCO}_{3} \%\end{array}$ & 3.92 & \multicolumn{2}{|c|}{$\begin{array}{l}\text { Available nutrients } \\
\text { (mg/kg soil) }\end{array}$} \\
\hline $\begin{array}{l}\text { Organic matter } \% \\
\mathrm{pH} \text { (Suspension } 1 \cdot 2.5 \text { ) }\end{array}$ & $\begin{array}{l}1.05 \\
8.07\end{array}$ & $\begin{array}{l}\mathrm{N} \\
\mathrm{P}\end{array}$ & $\begin{array}{l}43.9 \\
4.72\end{array}$ \\
\hline $\mathrm{EC} \mathrm{dS/m(saturated} \mathrm{paste} \mathrm{extract)}$ & 1.16 & $\mathrm{~K}$ & 287 \\
\hline
\end{tabular}

Farmyard manure was obtained from Farm, Fac. Agric., Mansoura Univ. and was added during the preparation of the experimental soil at rate of 20 or 30 $\mathrm{m}^{3} /$ fed. The chemical properties of farmyard manure are presented in Tables (2).

For bio-fertilizer treatments, the strains of bacteria used were Azotobacter chroococcum, Bacillus circulans and Mycorrhiza fungi. All inoculans were provided by Biofertilizer Unit, Fac. Agric., Ain Shams University. Biofertilizer solution was added to the wet soil twice to the root absorption zone of each plant at the recommended rate $(5$ $\mathrm{ml} /$ plant), the first one was added after one month of sowing and the second ones was added after a month from the first application of bio-fertilizer.

Table 2. Chemical analysis of farmyard manure.

\begin{tabular}{lcccccccc}
$\begin{array}{l}\text { Manure } \\
\text { characteristic }\end{array}$ & $\begin{array}{c}\mathbf{p H} \\
\mathbf{( 1 : 1 0 )}\end{array}$ & $\begin{array}{c}\mathbf{O . M} \\
\mathbf{( \% )}\end{array}$ & $\begin{array}{c}\mathbf{d S . m}^{-\mathbf{1}} \mathbf{( \mathbf { 1 } : \mathbf { 1 0 } )} \\
\text { Value }\end{array}$ & $\begin{array}{c}\text { Total N } \\
\mathbf{( \% )}\end{array}$ & $\begin{array}{c}\text { Total P } \\
\mathbf{( \% )}\end{array}$ & $\begin{array}{c}\text { Total K } \\
(\mathbf{\%})\end{array}$ & $\begin{array}{c}\text { C/N } \\
\text { Ratio }\end{array}$ & $\begin{array}{c}\text { Organic C } \\
(\%)\end{array}$ \\
\hline
\end{tabular}

\section{Humic acid:}

Commercial compound (Canada Humex) obtained from Fac. Agric., Ain Shams University; used as foliar spray at the concentration $1.5 \mathrm{ml} / \mathrm{L}$. Half experimental treatments received humic acid as spraying until drop-off by using a hand-sprayer at two times after 60 and 100 days from sowing.

\section{Treatments:}

1- $100 \%$ NPK (300, 200 and $50 \mathrm{~kg} /$ fed, recommended dose).

2- Farmyard manure (FYM) at $20 \mathrm{~m} 3 / \mathrm{fed}$.

3- $30 \% \mathrm{NPK}+$ farmyard manure at $20 \mathrm{~m} 3 /$ fed.

4- $30 \% \mathrm{NPK}+$ farmyard manure at $30 \mathrm{~m} 3$ / fed.

5- $30 \% \mathrm{NPK}+$ farmyard manure at $20 \mathrm{~m} 3 /$ fed + biofertilizer.

6- $30 \% \mathrm{NPK}+$ farmyard manure at $30 \mathrm{~m} 3 /$ fed + biofertilizer

7- $30 \% \mathrm{NPK}+$ farmyard manure at $20 \mathrm{~m} 3 /$ fed +biofertilizer +humic acid $(1.5 \mathrm{ml} / \mathrm{L})$.

8- $30 \% \mathrm{NPK}+$ farmyard manure at $30 \mathrm{~m} 3 /$ fed +biofertilizer +humic acid $(1.5 \mathrm{ml} / \mathrm{L})$.

9- Farmyard manure at $20 \mathrm{~m} 3 /$ fed + bio-fertilizer + humic acid $(1.5 \mathrm{ml} / \mathrm{L})$.

10- Farmyard manure at $30 \mathrm{~m} 3 /$ fed + bio-fertilizer + humic acid $(1.5 \mathrm{ml} / \mathrm{L})$.

A random sample of nine plants from each treatment were taken at the harvesting stage for determination of vegetative growth, i.e., plant height, branches number, herb fresh and dry weight. All fruits harvested from each treatment through harvesting period were weighted to calculate the total yield per plant and per fed. Also, Chemical constituents in herb and seeds such as total $\mathrm{N}, \mathrm{P}$ and $\mathrm{K}$ were decided according to the methods described by Mertens (2005 a and b) and Agrilasa (2002), respectively. Also, NO3-N was determined according to Singh (1988).

Statistical analysis:

The obtained data were statistically analyzed and means separation were compared with the least significant differences (L.S.D) test at $0.05 \%$ according to the method described by Gomez and Gomez (1984).

\section{RESULTS AND DISCUSSION}

\section{1- Vegetative growth characteristics.}

The effect of different fertilization types and humic foliar application on some vegetative Growth of caraway plant (plant height, number of branches per plant, herb fresh weight and herb dry weight) for the two studied seasons were shown in Table (3). It was cleared that treatments which was sprayed with humic acid produced the highest values of growth parameters; when compared with the treatments without humic acid.

Generally, the obtained results showed that the highest significant values of parameters of plant height $(114.55$ and $116.33 \mathrm{~cm})$, number of branches per plant (15.89 and 17.19), herb fresh weight (125.68 and $128.35 \mathrm{~g}$ ) and herb dry weight (32.74 and $34.71 \mathrm{~g}$ ) for the two studied seasons, respectively were recorded by caraway plants supplied with $30 \%$ NPK, farmyard manure $\left(30 \mathrm{~m}^{3} / \mathrm{fed}\right)$, biofertilizer and sprayed with humic acid. It is matter of importance to mentioned that the next positive increment in all measured parameters was obtained with caraway plants supplied with farmyard manure $\left(30 \mathrm{~m}^{3} / \mathrm{fed}\right)$, bio-fertilizer and sprayed with humic acid without using any chemical fertilizers. While, the application of $20 \mathrm{~m}^{3} / \mathrm{fed}$. farmyard manure gave the lowest values of plant growth parameters in both growing seasons as compared with all treatments.

These results showed the possibility of partial replacement of chemical fertilizers by using organic fertilizers, bio-fertilizer and humic acid to produce the highest values of plant growth parameters as compared with control treatment (100\% NPK, recommended dose). The importance of the addition of chemical fertilizers at small quantity may be due to that mineral fertilizer plays a major role in many physiological and biochemical processes such as cell division and elongation and metabolism of carbohydrates and protein compounds (Marschener, 1995). So, the small amounts of mineral fertilizer work as activation dose to stimulate plant growth at the first stages till the analysis of organic compounds and the release of nutrients. As Naguib (2011) reported that organic fertilizers could be as effective as chemical fertilizers over longer periods of use, 
improve the biodiversity and raise the abundance of soil organisms. Also, the significant effect of bio-fertilizer may be due to the effect of different strain groups such as nitrogen fixers (Azotobacter chroococcum), phosphate solubilizing microorganisms (Mycorrhizal fungi) and potassium solubilizing bacteria (Bacillus circulans) which help in availability of metals and their forms in the farmyard manure materials and increased levels of extractable N, P, K, $\mathrm{Fe}, \mathrm{Zn}$ and $\mathrm{Mn}$ (El-Karamany et al. 2000). The superiority of plant growth with addition of humic acid might be attributed to the role in protein synthesis, nutrients translocation, and foliar growth as reported by (Chen et al.,
2004). The role of humic acid in stimulating plant growth is by the assimilation of major and minor elements, enzyme activation, changes in membrane permeability, protein synthesis and the activation of biomass production (Ulukan, 2008). In addition, foliar spray with humic acid reduces the transpiration rate, and this in turn leads to keep higher water content in the plant tissues and hence might favor the plant metabolism, the physiological processes, photosynthetic rate and many other important functions that directly affect the plant growth (Ezzat et al., 2009).

Table 3. Vegetative growth of caraway plants as affected by fertilization types and humic acid during the two growing seasons of 2016 and 2017.

\begin{tabular}{|c|c|c|c|c|c|c|c|c|c|}
\hline \multirow{3}{*}{$\begin{array}{l}\text { Humic } \\
\text { acid }\end{array}$} & \multirow{3}{*}{$\begin{array}{c}\text { Treatments } \\
\begin{array}{c}\text { Fertilization } \\
\text { types }\end{array}\end{array}$} & \multicolumn{8}{|c|}{ Growth parameters } \\
\hline & & \multicolumn{2}{|c|}{$\begin{array}{l}\text { Plant height } \\
\text { (cm) }\end{array}$} & \multicolumn{2}{|c|}{$\begin{array}{c}\text { Branches } \\
\text { number/plant }\end{array}$} & \multicolumn{2}{|c|}{$\begin{array}{c}\text { Herb fresh } \\
\text { weight/plant (g) }\end{array}$} & \multicolumn{2}{|c|}{$\begin{array}{c}\text { Herb dry } \\
\text { weight/plant (g) }\end{array}$} \\
\hline & & 2012 & 2013 & 2012 & 2013 & 2012 & 2013 & 2012 & 2013 \\
\hline \multirow{6}{*}{ Without } & $100 \%$ NPK (control) & 102.11 & 105.26 & 12.57 & 14.24 & 113.69 & 115.53 & 24.36 & 26.29 \\
\hline & FYM $20 \mathrm{~m}^{3} / \mathrm{fed}$ & 89.15 & 91.30 & 8.89 & 9.95 & 62.77 & 64.71 & 9.86 & 10.69 \\
\hline & $30 \% \mathrm{NPK}+\mathrm{FYM} 20 \mathrm{~m}^{3} / \mathrm{fed}$ & 93.59 & 95.16 & 9.44 & 10.81 & 82.52 & 84.82 & 13.66 & 16.10 \\
\hline & $30 \% \mathrm{NPK}+\mathrm{FYM} 30 \mathrm{~m}^{3} / \mathrm{fed}$ & 97.67 & 99.31 & 10.77 & 12.27 & 89.28 & 91.45 & 15.23 & 17.62 \\
\hline & $30 \% \mathrm{NPK}+\mathrm{FYM} 20 \mathrm{~m}^{3} / \mathrm{fed}+$ Bio. & 95.30 & 96.92 & 11.33 & 13.29 & 98.34 & 100.27 & 19.18 & 21.47 \\
\hline & $30 \%$ NPK + FYM $30 \mathrm{~m}^{3} / \mathrm{fed}+$ Bio. & 99.83 & 101.85 & 12.55 & 14.38 & 106.32 & 108.82 & 21.54 & 22.71 \\
\hline \multirow{4}{*}{ With } & $30 \% \mathrm{NPK}+\mathrm{FYM} 20 \mathrm{~m}^{3} / \mathrm{fed}+$ Bio. & 108.43 & 110.32 & 13.77 & 15.14 & 116.39 & 118.72 & 27.35 & 29.31 \\
\hline & $30 \% \mathrm{NPK}+\mathrm{FYM} 30 \mathrm{~m}^{3} / \mathrm{fed}+\mathrm{Bio}$. & 114.55 & 116.33 & 15.89 & 17.19 & 125.68 & 128.35 & 32.74 & 34.71 \\
\hline & FYM 20 m³/fed + Bio. & 105.44 & 107.57 & 11.77 & 13.07 & 91.66 & 94.03 & 16.53 & 18.95 \\
\hline & FYM 30 m³ $^{3}$ fed + Bio. & 112.57 & 114.64 & 14.44 & 16.27 & 96.63 & 98.89 & 18.39 & 20.53 \\
\hline \multicolumn{2}{|c|}{ LSD at $5 \%$} & 0.65 & 0.86 & 0.26 & 0.64 & 0.13 & 0.77 & 0.08 & 0.47 \\
\hline
\end{tabular}

\section{2- Fruit yield.}

Fruit yield of caraway plants as affected by different fertilization regimes, in both studied seasons, is shown in Table (4). Data showed that the highest values of number of umbels per plant (46.44 and 48.91), fruit yield per plant $(25.73$ and $27.47 \mathrm{~g})$ and fruit yield per Fed. $(1235.2$ and $1318.4 \mathrm{~kg})$ were recorded by using $30 \%$ NPK, farmyard manure $\left(30 \mathrm{~m}^{3} / \mathrm{fed}\right)$, bio-fertilizer and spraying with humic acid, respectively for the two seasons. While, the lowest values of fruits yield parameters in both growing seasons were obtained with the application of $20 \mathrm{~m}^{3} / \mathrm{fed}$. farmyard manure as compared with all treatments.

The positive effect of organic fertilizer with humic acid was in harmony with those obtained by Gomaa and Youssef (2008) on caraway plants and Sharaf-El-Deen et al. (2012) on fennel plants. While, the positive effect of organic fertilizer with bio-fertilizer was in harmony with those obtained by Darzi (2012) on dill plants. The beneficial effect of those interactions (chemical, organic fertilizer, bio-fertilizer plus humic acid) on caraway fruits yield may be attributed to the enhancing of easily nutrients release into soil solution and to encourage their penetration through plant roots, as well as to developing antagonistic impacts toward pests and plant diseases (Ho and Hwan, 2000)

\section{3- Chemical constituents of herb and seeds.}

The chemical content of nitrogen, phosphor, potassium and nitrate in herb and seeds of caraway plants as a result of different fertilizers and folier application of humic acid is illustrated in Table $(5 \& 6)$.
Data in Table (5) presented that using the three different fertilizers types, i.e., NPK, farmyard manure, bio-fertilizer combined with spraying humic acid had a significant effect on the contents of N, P and $\mathrm{K}$ in herb of caraway plants in both seasons.

The largest nitrogen percentage in the two seasons (1.03 and $1.04 \%$, respectively) was recorded for the treated plants with $30 \% \mathrm{NPK}$, farmyard manure (30 $\mathrm{m}^{3} / \mathrm{fed}$ ), bio-fertilizer and sprayed with humic acid followed by the plants treated with $30 \%$ NPK, farmyard manure $\left(20 \mathrm{~m}^{3} / \mathrm{fed}\right)$, bio-fertilizer and sprayed with humic acid without significant differences. Also, it can be noticed that the highest Phosphorus percentage in the two seasons (1.03 and $1.04 \%$, respectively) was found in those plants treated with the same treatment [30\% NPK, farmyard manure $\left(30 \mathrm{~m}^{3} / \mathrm{fed}\right)$, bio-fertilizer and sprayed with humic acid] with a significant differences when compared with all treatments. For potassium percentage, it was cleared that the same previous treatment recorded an increase of potassium over all treatments in both growing seasons although this increase was not significant in the first season $(2.04 \%)$, but it was statistically significant $(2.22 \%)$ in the second one. The nitrate content in herb was affected by the different treatments used but the full recommended dose of chemical fertilization (100\% NPK) showed the highest significant levels of nitrate in the both seasons (32.33 and $32.37 \mathrm{mg} / \mathrm{kg}$, respectively). While, the lowest level of nitrate in the both seasons $(22.70$ and $22.93 \mathrm{mg} / \mathrm{kg}$, respectively) was obtained with farmyard manure (20 $\mathrm{m}^{3} / \mathrm{fed}$ ). These results are in accordance with those obtained by Valiki and Ghanbari (2015). 
Table 4. Fruits yield of caraway plants as affected by fertilization types and humic acid during the two growing seasons of 2016 and 2017.

\begin{tabular}{|c|c|c|c|c|c|c|c|}
\hline \multirow{3}{*}{$\begin{array}{l}\text { Humic } \\
\text { acid }\end{array}$} & \multirow{3}{*}{$\begin{array}{c}\text { Treatments } \\
\begin{array}{c}\text { Fertilization } \\
\text { types }\end{array}\end{array}$} & \multicolumn{6}{|c|}{ Yield components } \\
\hline & & \multicolumn{2}{|c|}{$\begin{array}{c}\text { Umbels } \\
\text { number/ plant }\end{array}$} & \multicolumn{2}{|c|}{ Fruit weight/ plant } & \multicolumn{2}{|c|}{$\begin{array}{c}\text { Fruit yield } \\
\text { (kg/fed) }\end{array}$} \\
\hline & & 2012 & 2013 & 2012 & 2013 & 2012 & 2013 \\
\hline \multirow{6}{*}{ Without } & $100 \%$ NPK (control) & 37.11 & 38.89 & 22.28 & 25.10 & 1069.6 & 1204.8 \\
\hline & FYM $20 \mathrm{~m}^{3} / \mathrm{fed}$ & 29.44 & 30.97 & 8.34 & 10.31 & 400.12 & 494.9 \\
\hline & $30 \% \mathrm{NPK}+\mathrm{FYM} 20 \mathrm{~m}^{3} / \mathrm{fed}$ & 34.55 & 36.59 & 11.45 & 13.69 & 549.8 & 657.0 \\
\hline & $30 \% \mathrm{NPK}+\mathrm{FYM} 30 \mathrm{~m}^{3} / \mathrm{fed}$ & 35.22 & 37.08 & 13.49 & 15.69 & 647.8 & 753.4 \\
\hline & $30 \% \mathrm{NPK}+\mathrm{FYM} 20 \mathrm{~m}^{3} / \mathrm{fed}+$ Bio. & 37.33 & 40.04 & 17.68 & 19.46 & 848.6 & 929.8 \\
\hline & $30 \%$ NPK + FYM $30 \mathrm{~m}^{3} /$ fed + Bio. & 39.78 & 41.88 & 19.64 & 21.52 & 942.7 & 1033.0 \\
\hline \multirow{4}{*}{ With } & $30 \% \mathrm{NPK}+\mathrm{FYM} 20 \mathrm{~m}^{3} / \mathrm{fed}+$ Bio. & 42.22 & 44.85 & 22.42 & 25.27 & 1076.3 & 1213.1 \\
\hline & $30 \% \mathrm{NPK}+\mathrm{FYM} 30 \mathrm{~m}^{3} / \mathrm{fed}+$ Bio. & 46.44 & 48.91 & 25.73 & 27.47 & 1235.2 & 1318.4 \\
\hline & FYM $20 \mathrm{~m}^{3} /$ fed + Bio. & 36.33 & 38.40 & 16.43 & 18.49 & 788.8 & 897.0 \\
\hline & FYM $30 \mathrm{~m}^{3} / \mathrm{fed}+$ Bio. & 38.11 & 41.10 & 18.77 & 21.00 & 900.8 & 1008.2 \\
\hline \multicolumn{2}{|c|}{ LSD at $5 \%$} & 0.58 & 0.93 & 0.16 & 0.72 & 7.7 & 34.47 \\
\hline
\end{tabular}

Table 5. Effect of fertilization types and humic acid on $\mathrm{N}, \mathrm{P}, \mathrm{K}$ and $\mathrm{No}_{3}-\mathrm{N}$ in herb of caraway plants during the two growing seasons of 2016 and 2017.

\begin{tabular}{|c|c|c|c|c|c|c|c|c|c|}
\hline \multirow{3}{*}{$\begin{array}{l}\text { Humic } \\
\text { acid }\end{array}$} & \multirow{3}{*}{$\begin{array}{c}\text { Treatments } \\
\begin{array}{c}\text { Fertilization } \\
\text { types }\end{array}\end{array}$} & \multicolumn{8}{|c|}{ Constituents } \\
\hline & & \multicolumn{2}{|c|}{$\mathrm{N} \%$} & \multicolumn{2}{|c|}{$\mathbf{P \%}$} & \multicolumn{2}{|c|}{ K \% } & \multicolumn{2}{|c|}{ NO3-N mg/ kg } \\
\hline & & 2012 & 2013 & 2012 & 2013 & 2012 & 2013 & 2012 & 2013 \\
\hline \multirow{6}{*}{ Without } & $100 \%$ NPK (control) & 0.96 & 0.96 & 0.256 & 0.258 & 1.92 & 1.94 & 32.33 & 32.37 \\
\hline & FYM $20 \mathrm{~m}^{3} /$ fed & 0.74 & 0.72 & 0.224 & 0.226 & 1.52 & 1.55 & 22.70 & 22.93 \\
\hline & $30 \% \mathrm{NPK}+\mathrm{FYM} 20 \mathrm{~m}^{3} / \mathrm{fed}$ & 0.83 & 0.84 & 0.228 & 0.230 & 1.67 & 1.68 & 26.97 & 27.10 \\
\hline & $30 \% \mathrm{NPK}+\mathrm{FYM} 30 \mathrm{~m}^{3} / \mathrm{fed}$ & 0.88 & 0.89 & 0.232 & 0.235 & 1.70 & 1.73 & 24.80 & 24.90 \\
\hline & $30 \% \mathrm{NPK}+\mathrm{FYM} 20 \mathrm{~m}^{3} / \mathrm{fed}+$ Bio. & 0.90 & 0.90 & 0.239 & 0.242 & 1.73 & 1.74 & 29.73 & 29.90 \\
\hline & $30 \% \mathrm{NPK}+\mathrm{FYM} 30 \mathrm{~m}^{3} / \mathrm{fed}+\mathrm{Bio}$. & 0.91 & 0.92 & 0.245 & 0.247 & 1.84 & 1.86 & 27.77 & 28.17 \\
\hline \multirow{4}{*}{ With } & $30 \% \mathrm{NPK}+\mathrm{FYM} 20 \mathrm{~m}^{3} /$ fed + Bio. & 1.01 & 1.02 & 0.270 & 0.275 & 1.99 & 2.01 & 31.10 & 31.27 \\
\hline & $30 \% \mathrm{NPK}+\mathrm{FYM} 30 \mathrm{~m}^{3} / \mathrm{fed}+$ Bio. & 1.03 & 1.04 & 0.282 & 0.285 & 2.04 & 2.22 & 28.23 & 28.37 \\
\hline & FYM $20 \mathrm{~m}^{3} / \mathrm{fed}+$ Bio. & 0.82 & 0.82 & 0.214 & 0.218 & 1.60 & 1.65 & 25.77 & 25.93 \\
\hline & FYM $30 \mathrm{~m}^{3} / \mathrm{fed}+$ Bio. & 0.91 & 0.93 & 0.241 & 0.245 & 1.79 & 1.82 & 23.70 & 23.87 \\
\hline \multicolumn{2}{|c|}{ LSD at 5\% } & 0.04 & 0.05 & 0.005 & 0.007 & 0.06 & 0.09 & 0.93 & 0.87 \\
\hline
\end{tabular}

Table 6. Effect of fertilization types and humic acid on N, P, K and No3-N in seeds of caraway plants during the two growing seasons of 2016 and 2017.

\begin{tabular}{|c|c|c|c|c|c|c|c|c|c|}
\hline \multirow{3}{*}{$\begin{array}{l}\text { Humic } \\
\text { acid }\end{array}$} & \multirow{3}{*}{$\begin{array}{c}\text { Treatments } \\
\begin{array}{c}\text { Fertilization } \\
\text { types }\end{array}\end{array}$} & \multicolumn{8}{|c|}{ Measurements } \\
\hline & & \multicolumn{2}{|c|}{$\mathrm{N} \%$} & \multicolumn{2}{|c|}{$\mathbf{P} \%$} & \multicolumn{2}{|c|}{$\mathrm{K} \%$} & \multicolumn{2}{|c|}{ NO3-N mg/ kg } \\
\hline & & 2012 & 2013 & 2012 & 2013 & 2012 & 2013 & 2012 & 2013 \\
\hline \multirow{6}{*}{ Without } & $100 \%$ NPK (control) & 1.67 & 1.68 & 0.344 & 0.345 & 2.24 & 2.30 & 21.47 & 21.53 \\
\hline & FYM $20 \mathrm{~m}^{3} /$ fed & 1.33 & 1.37 & 0.286 & 0.289 & 1.84 & 1.87 & 14.67 & 14.93 \\
\hline & $30 \% \mathrm{NPK}+\mathrm{FYM} 20 \mathrm{~m}^{3} / \mathrm{fed}$ & 1.45 & 1.48 & 0.303 & 0.308 & 1.97 & 2.01 & 19.43 & 19.37 \\
\hline & $30 \% \mathrm{NPK}+\mathrm{FYM} 30 \mathrm{~m}^{3} / \mathrm{fed}$ & 1.53 & 1.55 & 0.318 & 0.321 & 2.07 & 2.09 & 17.93 & 18.23 \\
\hline & $30 \% \mathrm{NPK}+\mathrm{FYM} 20 \mathrm{~m}^{3} / \mathrm{fed}+$ Bio. & 1.60 & 1.62 & 0.324 & 0.325 & 2.17 & 2.25 & 17.47 & 17.50 \\
\hline & $30 \% \mathrm{NPK}+\mathrm{FYM} 30 \mathrm{~m}^{3} / \mathrm{fed}+$ Bio. & 1.60 & 1.61 & 0.329 & 0.332 & 2.20 & 2.25 & 16.20 & 16.33 \\
\hline \multirow{4}{*}{ With } & $30 \% \mathrm{NPK}+\mathrm{FYM} 20 \mathrm{~m}^{3} / \mathrm{fed}+\mathrm{Bio}$ & 1.73 & 1.75 & 0.358 & 0.361 & 2.36 & 2.40 & 20.20 & 20.53 \\
\hline & $30 \% \mathrm{NPK}+\mathrm{FYM} 30 \mathrm{~m}^{3} / \mathrm{fed}+\mathrm{Bio}$ & 1.83 & 1.84 & 0.373 & 0.374 & 2.49 & 2.64 & 18.53 & 18.73 \\
\hline & FYM $20 \mathrm{~m}^{3} / \mathrm{fed}+$ Bio. & 1.38 & 1.39 & 0.298 & 0.301 & 1.88 & 1.89 & 16.80 & 16.83 \\
\hline & FYM $30 \mathrm{~m}^{3} / \mathrm{fed}+$ Bio. & 1.50 & 1.51 & 0.311 & 0.314 & 2.05 & 2.20 & 15.83 & 16.13 \\
\hline \multicolumn{2}{|c|}{ LSD at $5 \%$} & 0.05 & 0.05 & 0.007 & 0.008 & 0.07 & 0.18 & 1.08 & 0.67 \\
\hline
\end{tabular}

Also, data in Table (6) presented that using the three different fertilizers types, i.e., NPK, farmyard manure, biofertilizer combined with spraying humic acid had a significant effect on the contents of $\mathrm{N}, \mathrm{P}$ and $\mathrm{K}$ in seeds of caraway plants in both seasons. The treatment of $30 \% \mathrm{NPK}$, farmyard manure $\left(30 \mathrm{~m}^{3} / \mathrm{fed}\right)$, bio-fertilizer and sprayed with humic acid showed significantly higher content of $\mathrm{N}, \mathrm{P}$, and $\mathrm{K}$ percentage in seeds compared with all treatments in both seasons. Combined between bio-fertilizer and organic manure one of the reasons which increase the nutrient concentrations and this suggested to be due to influence of bio- fertilizer in uptake of essential nutrients from organic manure that contains different organic compounds (Dalal, 1977) which are easily released in soil and become available to plants (Martin, 1973).
For nitrate content, the full recommended dose of mineral fertilization (100\% NPK) showed the highest levels of nitrate in the both seasons (21.47 and $21.53 \mathrm{mg} / \mathrm{kg}$, respectively). While, the lowest level of nitrate in the both seasons (14.67 and $14.93 \mathrm{mg} / \mathrm{kg}$, respectively) was obtained with farmyard manure $\left(20 \mathrm{~m}^{3} / \mathrm{fed}\right)$. This is in agreement with Hassan and Ali (2013) who reported that the organic fertilization reduces seed content of nitrate. It is matter of importance to mentation that the other treatments which include less rates of mineral fertilizers (30 \% NPK) supplemented with rates of organic fertilization, bio-fertilizer and sprayed with humic acid showed significantly lower level of nitrate when compared with control (100\% NPK, recommended dose). 


\section{REFERENCES}

Adani, F., P. Genevini and P. Zaccheo (1998). The effect of commercial humic acid on tomato plant growth and mineral nutrition.J. Plant Nutr. 21:561-575.

Agrilasa (2002). Handbook on feeds and plant analyses. Agrilasa, Pretoria. South Africa.

Chen, Y., M. De. Nobili and T. Aviad (2004). Stimulatory effect of humic substances on plant growth. In Soil organic matter in sustainable agriculture. (Eds Magdoff F, Weil RR). Boca Raton. crop production. Egypt J. Appl. Sci. 15(11): 137-155.

Dalal, R. C. (1977). Soil Organic Phosphorus. Advances in Agronomy 29:83-117.

Darzi, M. T. (2012). Influence of organic fertilizer and biostimulant on the growth and biomass of dill (Anethum graveolens). International Journal of Agriculture and Crop Sciences 4(3): 98-102.

Dyduch, J., A. Najda and N. Brzozowski (2006). Growth and chemical content of caraway (Carum carvi L.) in the first year of cultivation. Folia Hortic. 1:108-112.

El- Karamany, M. F., M. K. A. Ahmed, A. A. Bahr and M. O. kabesh (2000). Utilization of bio-fertilizers in field crop production. Egypt J. Appl.Sci.15:137- 145.

El-Nagar, E. M. (1996). Effect of applying some organic residuse to sandy calcareous soils on growth and composition of some plants. M. Sc. Thesis. Fac. Agric. Mansoura Univ., Egypt

Ezzat, A., U. Saif Eldeen and A. Abd El-Hameed (2009). Effect of irrigation water quantity, antitranspirant and humic acid on growth, yield, nutrients content and water use efficiency of potato (Solanum tuberosum L.).J.Agric.Sci.Mansoura Univ.34(12):11585-11603.

Fortun, C., A. Fortun and G. Almendros (1989). The effect of organic materials and their humified fractions on the formation and stabilization of soil aggregates. The Science of the total Environment 81/82: 561568.

Ghosh, B. C. and R. Bhat (1998). Environmental hazards of nitrogen loading in wetland rice fields. Environ Pollut. 102: 123-126.

Gomaa, A .O. and A. S. Youssef (2008). Efficiency of bio and chemical fertilization in presence of humic acid on growth performance of caraway Hort. Dept., Fac. Agric., Moshtohor, Benha University, 4th Scientific Conference of the Agricultural and Biological Research Division under the theme "Safe Agriculture Products for Health and Environment by Using Recent Technologies; May 5-6, National Research Centre Agricultural and Biological Research Division Cairo, Egypt".

Gomez, K. A. and A. A. Gomez (1984). "Statistical Procedures for Agricultural Research". John Wiley and Sons, Inc., New York.pp:680.

Hassan, F. A. S. and E. F. Ali (2013). A comparative study between traditional mineral nutrition and other alternative sources on anise plant. Europe. J. Sci. Res. 106(2): 201-212.
Ho, H. O. and J. K. Hwan (2000). The study on the plant growth hormones; in EM Technology and Nature Farming, 6th Inter. Conf., held in Kyusei, Pretoria, South Africa: 15-21.

Kluszczyñska, D. (2002). Caraway in medical care and housekeeping. Wiad. Ziel. 44(4): 13-15.

Kocourkova, B., J. Sedlakova, and V. Holubova (1999). Morfologicke a kvalitativni znaky registrovanych odrud. In : Proc. Conf. Caraway in present plant production. MZLU Brno: 34-41.

Marschner, H. (1995). Functions of mineral nutrients. In: Mineral nutrition of higher plants 2nd (ed.). Macronutrents: 299-312.

Martin, J. K. (1973). The influence of rhizosphere microflora on the availability of 32P myo-inositol hexaphospate phosphorus to wheat. Soil Biol. Biochem 5:473-483.

Mertens, D. (2005a). AOAC official method 922.02. Plants preparation of laboratuary sample. Official methods of analysis, 18th edn. North Frederick Avenue, Gaitherburg, Maryland, pp.1-2

Mertens, D. (2005b). AOAC Official method 975.03. Metal in plants and pet foods. Official methods of analysis, 18th edn. North Frederick Avenue, Gaitherburg, Maryland, pp. 3-4

Naguib, N. Y. M. (2011). Organic vs. chemical fertilization of medicinal plants: A concise review of researches. Advances in Environ. Bio. 5(2): 394-400.

Olle, M. and I. Bender (2010). The content of oils in umbelliferous crops and its formation. Agron. Res., 8 (Special Issue): 687-696.

Sedlakova, J., V. Kuban, V. Holubova and B. Kocourkova (1998). Stanoveni silic v kminu. In: Proc. Conf. Analysis of organic compounds in environment. 2Theta, K. Lhotka: 120-126.

Sembratowicz, I. and A. Czech (2005). Natural antioxidants in the food. Post. Nauk Roln. 1: 75-88.

Sharaf-El-Deen, M. N., H. Y. Massoud and A. A. Manal (2012). Effect of humic acid and fertilizers types on vegetative growth, fruit yield, essential oil quality of fennel (Foeniculum vulgare mill.) plants. J. Plant Production, Mansoura Univ. 3 (2): $201-215$.

Singh, J. P. (1988). A rapid method for determination of nitrate in soil and plant extracts. Plant and soil. 110: 137-139.

Sturz, A. V. and B. R. Christie (2003). Beneficial microbial allelopathies in the root zone.Soil Till.Res.72:107123.

Ulukan, H. (2008). Effect of soil applied humic acid at different sowing times on some yield components in wheat (Triticum spp.). Int. J. Bot. 4(2): 164-175.

Valiki, S. and S. R. H. Ghanbari (2015). Comparative examination of the effect of manure and chemical fertilizers on yield and yield components of rosemary (Rosemarinus officinalis L.) .Department of Agronomy, Qaemshahr Branch, Islamic Azad University, Qaemshahr, Iran International Journal of Agronomy and Agricultural Research 6 (2): 29-37.

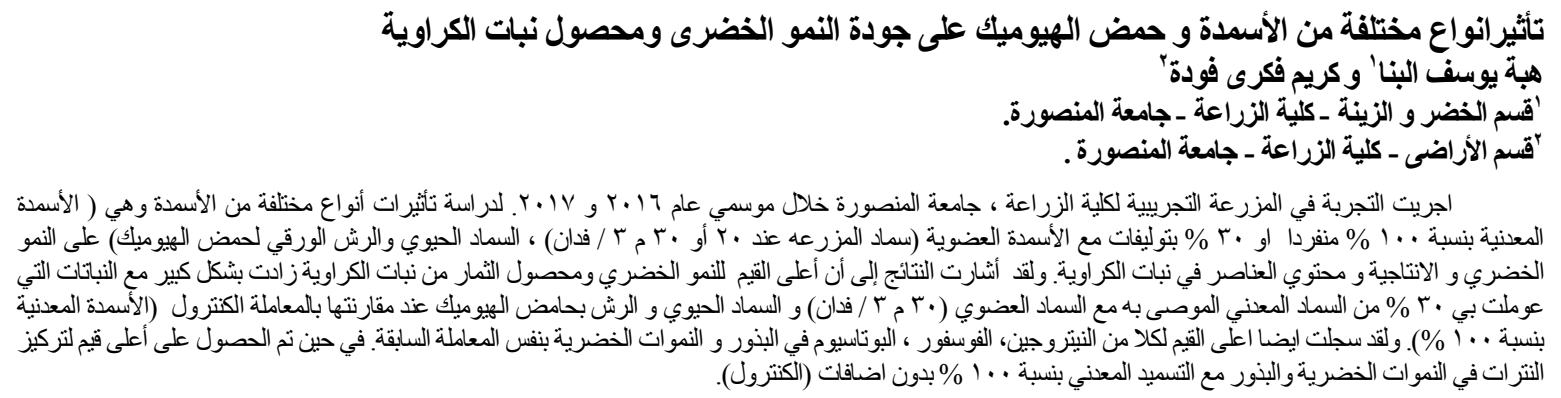

